\title{
塔里木盆地成藏旋回初论*
}

吕修祥 张一伟 金之钧

(石油大学盘地研究中心, 北京 102200)

\section{关键词成藏旋回 油气藏演化塔里木盆地}

盆地发育演化的旋回性特点, 造就了塔里木盆地内发育有多套生油层系. 多次生、排烃的 出现, 带来了多次油气聚集成藏, 而多次构造运动, 又可能导致已形成的油气藏被调整或被破坏.

\section{1 成藏旋回的基本概念}

成藏旋回是与盆地发育演化的多旋回性密切相关的. 虽然我国东部有些断陷-坳陷盆地 (如渤海湾盆地) 也表现出多旋回性的特点 ${ }^{[1]}$, 但由于盆地形成时代比较新, 烃源岩相对集中, 热演化也是一次到位, 油气藏的形成演化也就比较简单. 而塔里木盆地却与之截然不同, 如在 同一油气藏中常有稠油与轻质油共生、泑青砂与可动油共生、凝析油气与正常原油共生、降解 油与未降解油共生的现象 ${ }^{[2]}$, 事实表明多次生、排烃期、多次运移再分配及多期次成藏是塔里 木盆地油气藏形成演化的一大特点. 因此我们设想如果能在纵向上分出几个层次来探讨油气藏 形成演化史, 必将大大提高人们对油气分布规律的认识, 于是便产生了成藏旋回这一概念.

成藏旋回指的是油气从源岩排出、运移、聚集成藏, 及在随后的各种地质作用的影响下, 使 业已形成的油气藏重新调整或被破坏的全过程. 每一旋回对应于盆地持续下沉生、排烃开始 至隆升剥蚀结束的整个过程.

原则上讲, 成藏旋回在时间上是连续的, 但在少数情况下, 后一旋回的破坏作用的影响, 可 能波及到上一旋回保存下来的油气藏, 对这类情况通过分析油气藏的形成期和破坏期是不难 鉴别出来的.

\section{2 塔里木盆地成藏旋回划分}

单井埋藏史分析结果表明, 塔里木盆地的升降旋回可以大致分为 3 期. 烃源岩的演化史 也大致有 3 次排烃高峰期, 每一次排烃高峰期就带来了一次油气藏的形成演化过程, 据此可将 塔里木盆地划分为三大成藏旋回 (图 1).

(1)成藏旋回 I(奥陶纪末～泥盆纪末) 圈闭主要为寒武系～奥陶系内幕圈闭及志留 系背斜圈闭, 油气来源则为寒武系 下奥陶统碳酸盐岩生油层的第 1 次排烃高峰. 随后的强 烈隆升剥蚀使第 1 期形成的油气藏大多被破坏. 如哈 1 井志留系的饬青砂便是这一期破坏作 用留下的产物.

1995-12-25 收稿, 1996-04-06 收修改稿

* 国家教委博士后基金资助项目 
（2）成藏旋回 II （石炭纪～侏罗纪 末）圈闭主要包括晚海西期形成的 下奥陶统断垒、奥陶系挤压滑脱背斜、 上泥盆统 石炭系的挤压背斜等, 油气 则是在二叠纪时下伏烃源岩的排烃高 峰期聚集的. 随后一系列的构造活动 如翅倾活动、差异升降导致的隆升剥蚀 作用等, 或使已形成的油气藏受到调整 (如塔中 4 号东河砂岩断背斜油藏), 或 使其被破坏 (如英买 7 号下奥陶统潜山 背斜中残存的沥青). 在保存条件比较 好的地区油气藏可直接保存下来 (如轮 南下奥陶统潜山油藏及英买 1 号背斜

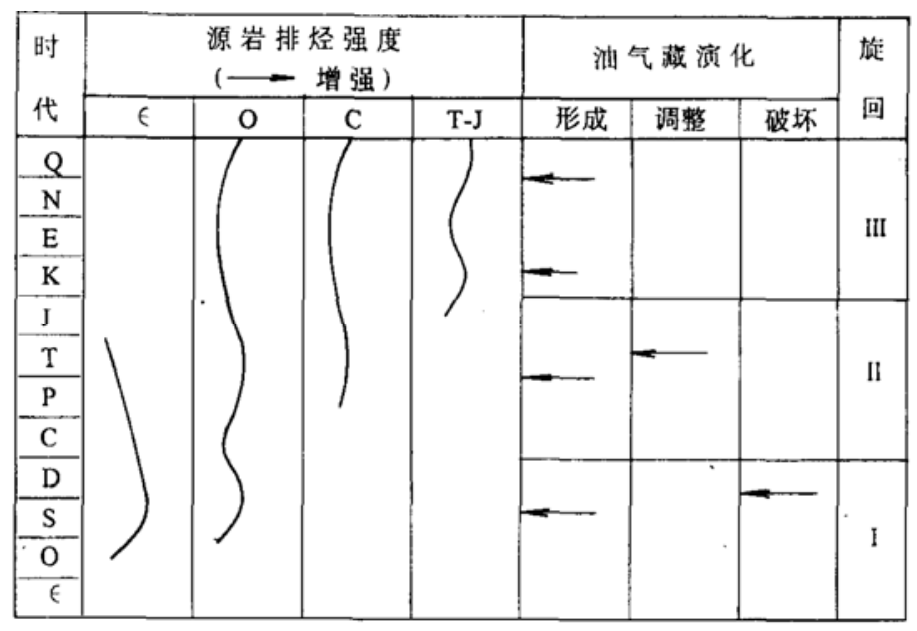

图 1 塔里木盆地成藏旋回划分图 内幕油气藏等).

(3) 成藏旋回 III (白亚纪一第四纪)

圈闭包括燕山期形成的背斜、断背斜、断块及残存 的早期圈闭, 油气来源既有盆地内第 3 次排烃高峰提供的油气, 同时也有早期形成的油气藏在 调整过程中, 沿断层向上运移的油气. 油气藏形成期主要在新第三纪. 这一阶段实际上是新 油气藏与形成与部分前期油气藏调整的过程. 因此, 该成藏旋回具有多油气源、多期形成的圈 闭、多层位成藏、成藏期短、保存条件好、成藏有效性高等特点, 现今发现的油气储量中属该期 成藏的比例很高.

油源对比结果表明英买 7 号油气藏的油气来自于库车坳陷的三叠系暗色泥岩. 显然, 英 买 7 号油藏是第 3 个成藏旋回的产物. 但下奥陶统碳酸盐岩中的沥青却是先期的油气聚集为 后期的破坏所遗留下来的产物.

\section{3 塔里木盆地成藏旋回控油规律}

\section{1 油气成藏的期次性}

总体上看, 塔里木盆地油气藏形成具有 3 个主要成藏期, 大致对应于盆地的 3 个排烃高峰 期. 破坏作用以旋回 I 最为明显, 隆升剥蚀一方面导致了已成油气藏的破坏, 但另一方面也抑 制了下伏源岩热演化的继续进行, 为二次生烃创造了条件. 调整作用以旋回 II 最为明显, 旋回 III形成的油气藏很少经历破坏或调整,如库车油气系统中的油气藏.

\section{2 油气纵向分布的层次性}

我们可以用下、中、上 3 个层次来总结塔里木盆地油气在纵向上的分布,下油气层以下奥 陶统为主要含油气层系, 油气聚集发生在第 II 成藏旋回期. 目前尚未发现形成于第 I 成藏旋 回期的油气藏, 克拉通盆地的大油气田往往都是原生油气藏 ${ }^{[3]}$, 因此下一步应在下油气层中 寻找原生油气藏. 中油气层以东河砂岩、石炭系为主要含油层系, 多数形成于第 II 成藏旋回. 典型实例有位于塔北隆起的东河塘油田、位于塔中低凸起的亿吨级塔中 4 油田. 上油气层分 布于中、新生界中, 形成于第吕成藏旋回期. 既有三叠 侏罗系源岩的排烃运聚, 也有已成油 气藏的调整、运聚如轮南三叠系油田. 


\section{3 油气平面分布的分区性}

不同含油层系在平面上的分布具有明显的分区性,下油气层集中在满加尔凹陷南、北两侧 的古隆起上. 中油气层叠置在两个古隆起之上及古隆起的斜坡部位. 上油气层在盆地北部明 显受库车油气系统烃源岩的控制, 分布于库车坳陷及塔北隆起北部, 在盆地西南部则受西南坳 陷源岩及油源断层的控制. 轮南地区三叠系油气藏则受益于下伏油气藏的调整.

\section{参考 文献}

1 李德生. 中国含油气盆地的构造类型. 石油学报, 1982, (3) $3: 1 \sim 13$

2 Liang Digang. New progress in petroleum exploration of Tarim basin. China Oil \& Gas, 1994, 1(2): 41 48

3 何登发,董大忠,吕修样等. 克拉通盆地分析. 北京: 石油工业出版社, 1996 